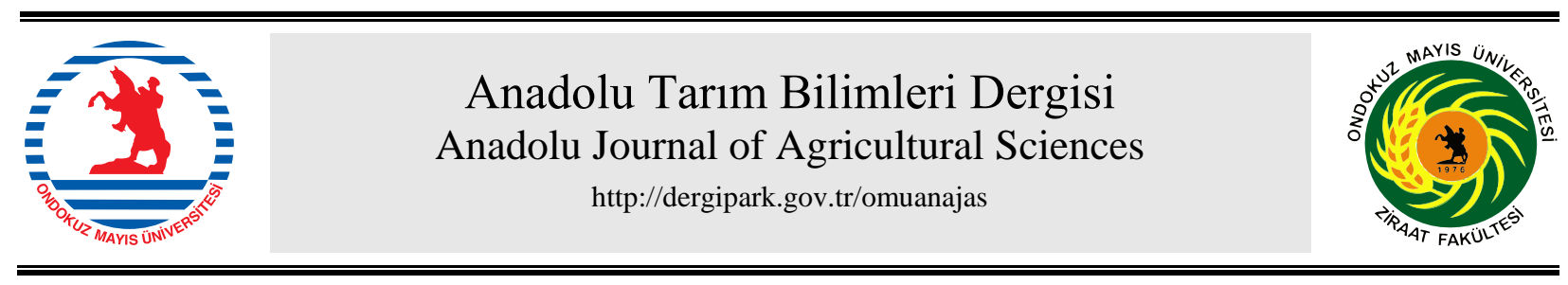

\section{Araştırma/Research}

Anadolu Tarım Bilim. Derg./Anadolu J Agr Sci, 34 (2019) ISSN: 1308-8750 (Print) 1308-8769 (Online) doi: 10.7161/omuanajas.470078

\title{
Farklı kökenli arpa çeşitlerinin tane verimi ve bazı kalite özellikleri yönünden değerlendirilmesi
}

\author{
Özge Doğanay Erbaş Köse, Zeki Mut* \\ Bilecik Şeyh Edebali Üniversitesi Ziraat ve Doğa Bilimleri Fakültesi, Tarla Bitkileri Bölümü, Bilecik \\ Sorumlu yazar/corresponding author:zeki.mut@bilecik.edu.tr
}

Geliş/Received 12.10.2018 Kabul/Accepted 18.03.2019

\begin{abstract}
ÖZET
Arpa malt sanayinde ve hayvan beslenmesinde kullanılan önemli bir tahıldır. Bu çalışma, Yozgat koşullarında 13 arpa çeşidinin tane verimi ve bazı kalite özelliklerini belirlemek amacıyla 2012-2015 yetiştirme sezonlarında 3 yıl süreyle tesadüf blokları deneme desenine göre üç tekrarlamalı olarak yürütülmüştür. Üç yıllık ortalamalara göre çeşitlerin tane verimi $278.7-375.2 \mathrm{~kg} \mathrm{da}^{-1}$, bitki boyu 67.66$91.83 \mathrm{~cm}$, hektolitre ağırlığ $56.17-67.41 \mathrm{~kg}$, bin tane ağırlığı 33.73-45.56 g, kül oranı \% 1.771-2.097, yağ oranı \% 1.581-2.085, protein oranı \% 12.32-13.39, nişasta oranı \% 57.15-62.40, ADF oranı \% 5.898-7.523, NDF oranı \% 22.00-24.87, K içeriği \% 0.600-0.692, P içeriği \% 0.399-0.425 ve Mg içeriği \% 0.153-0.175 arasında değişmiştir. Tane verimi ile bitki boyu arasında olumlu ve önemli ilişki belirlenmiștir. Çalıșmada, sırasıyla Erginel-90, Larende, Aydanhanım, Zeynelağa, Scarpia ve Özdemir05 çeşitleri en yüksek tane verimine sahip çeşitler olmuştur. Aydanhanım çeşidi yüksek tane verimi yanında bitki boyu, bin tane ağırlığı, hektolitre ağırlığı ve nişasta içeriği bakımından öne çıkan çeşit olmuştur.
\end{abstract}

Determination of different origin barley cultivars in terms of grain yield and some quality traits

\begin{abstract}
Barley is an important cereal used in malt industry and in animal feeding. This study was carried out according to the randomized complete block design with three replications for 3 years in the growing season of 2012-2015 in order to determine the grain yield and some quality characteristics of 13 barley cultivars in Yozgat conditions. Over the years, grain yields of the cultivars varied between 278.7-375.2 $\mathrm{kg} \mathrm{da}^{-1}$, plant heights between $67.66-91.83 \mathrm{~cm}$, test weights between $56.17-67.41 \mathrm{~kg}$, thousand grain weights between 33.73-45.56 g, ash contents between 1.771-2.097\%, fat ratios between 1.581-2.085\%, protein contents between 12.32-13.39\%, starch contents between 57.15-62.40\%, ADF contents between 5.898-7.523\%, NDF contents between 22.00-24.87\%, K contents between 0.600-0.692 \%, P contents between $0.399-0.425 \%$ and $\mathrm{Mg}$ contents between $0.153-0.175 \%$. Relationship between grain yields with plant height was determined in positive and significant. The highest grain yield was obtained from Erginel-90, Larende, Aydanhanım, Zeynelağa, Scarpia ve Özdemir-05 cultivars, respectively. Aydanhanım cultivar with high grain yield was in the superior position in terms of plant height, thousand grain weight, test weight and starch content
\end{abstract}

\section{Giriş}

Arpa (Hordeum vulgare L.) tanesindeki yüksek protein içeriği nedeniyle çoğunlukla hayvan beslenmesi ve yüksek ekstrakt verimi ile malt yapımında kullanılması yanında, sindirilebilir lif ve yüksek $\beta$ glukan içeriğinden dolayı son yıllarda insan besini olarak da kullanılmaktadır (Alkan ve Kandemir, 2015).
Anahtar Sözcükler:

Arpa

Verim

Kalite

Protein

Nişasta
Keywords:

Barley

Yield

Quality

Protein

Starch

(C) OMU ANAJAS 2019

Dünyada ekim alanı 46.9 milyon hektar, üretimi 141.2 milyon ton olan arpanın (FAO, 2017), ülkemizde 2.42 milyon ha ekim alanı ve 7.1 milyon ton üretimi ile tahıllar içerisinde ekiliş ve üretim bakımından ikinci sırada yer almaktadır (TÜIKK, 2017). Yozgat ilinde arpa ekim alanı 362.2 bin da, üretimi 85.1 bin ton ve verimi $230 \mathrm{~kg} \mathrm{da}^{-1}$ olarak gerçekleşmiştir (TÜIKK, 2017). Çeşit ve iklim koşullarına göre arpanın fiziksel özellikleri ve kimyasal içeriği değişkenlik göstermektedir (Gou ve 
ark., 2003). Arpa tuzluluğa dayanıklılığından dolayı çoraklaşma görülen bölgelerde toprak 1slahı için kullanılan, sulu alanlarda ise endüstri bitkileri ve baklagiller ile iyi bir münavebe oluşturan önemli bir kültür bitkisidir (Topal, 1993).

Arpada hektolitre ağırlığı, bin tane ağırlı ̆̆ 1 , tane tekdüzeliği gibi fiziksel özellikler yanında protein, yağ, nişasta ve kül içerikleri ile sindirilebilirliği gibi kimyasal özellikler kalite açısından ele alınan önemli özelliklerdir. $\mathrm{Bu}$ amaçla bir bölge ya da ilde yetiştirilecek çeşitlerde yüksek tane verimi yanında istenilen kalite vasıflarının belirlenmesi oldukça önemlidir. Bu çalışma Yozgat ya da benzer ekolojilerde üreticilerin kaynağını ve özelliklerini bilmedikleri çeşitlerin yerine ikame edebilecek yüksek verimli ve istenilen kalite özelliklerine sahip çeşitlerin belirlenmesi amacıyla yapılmıştır.

\section{Materyal ve Yöntem}

$\mathrm{Bu}$ çalışma, 2012-2015 yılları arasında Yozgat'ın Yerköy ilçesinde yer alan Bozok Üniversitesi Araştırma ve Uygulama Merkezine ait arazide üç yıl süreyle yürütülmüştür. Materyal olarak Türkiye'de yaygın olarak yetiştirilen bazı arpa çeşitleri ile farklı özel kuruluşlardan temin edilen toplam 13 arpa çeşidi (başak tipi 2 sıralı 8 adet, 6 sıralı 5 adet) kullanılmıştır (Çizelge 1). Denemelerde ekim $\mathrm{m}^{2}$ ye 500 tohum olacak şekilde ve $8 \mathrm{~m}$ uzunluğundaki parsellere, 8 sira ve sira arası 20 $\mathrm{cm}$ olacak şekilde parsel mibzeriyle yapılmıştır.

Çizelge 1. Denemede kullanılan çeşitlerin isimleri, başak tipleri ve tescil edildiği kuruluşlar

\begin{tabular}{lcl}
\hline \multicolumn{1}{c}{ Çeşit adı } & Başak tipi & \multicolumn{1}{c}{ Tescil edildiği veya çeşitlerin temin edildiği yerler } \\
\hline Angela & 6 sıralı & Alfa Tohum Tarım Gıda İnş.Paz. San. Tic. Ltd. Şti. \\
Epona & 6 siralı & Alfa Tohum Tarım Gıda İnş.Paz. San. Tic. Ltd. Şti. \\
Erginel-90 & 6 siralı & Geçit Kuşağı Tarımsal Araştırma Enstitüsü \\
Kondrat & 6 sıralı & Marmara Tohum Geliştirme A.Ş. \\
Scarpia & 6 sıralı & Marmara Tohum Geliştirme A.Ş. \\
Aydanhanım & 2 siralı & Tarla Bitkileri Merkez Araştırma Enstitüsü \\
Bülbül-89 & 2 siralı & Tarla Bitkileri Merkez Araştırma Enstitüsü \\
Larende & 2 siralı & Bahri Dağdaş Uluslararası Tarımsal Araştırma Enstitüsü \\
Metaxa & 2 siralı & Marmara Tohum Geliştirme A.Ş. \\
Özdemir-05 & 2 siralı & Geçit Kuşağ1 Tarımsal Araştırma Enstitüsü \\
Sarmat & 2 siralı & Marmara Tohum Geliştirme A.Ş. \\
Tarm-92 & 2 siralı & Tarla Bitkileri Merkez Araştırma Enstitüsü \\
Zeynel Ağa & 2 siralı & Tarla Bitkileri Merkez Araştırma Enstitüsü \\
\hline
\end{tabular}

Ekim işlemi birinci yıl 15 Ekim 2012, ikinci yıl 14 Ekim 2013 ve üçüncü yıl 11 Ekim 2014 tarihlerinde yapılmıştır. Tesadüf Blokları Deneme Desenine göre 3 tekrarlı olarak kurulan denemelere toprak tahlil sonucuna göre dekara $9 \mathrm{~kg}$ saf $\mathrm{N}$ ve $7 \mathrm{~kg} \mathrm{P} \mathrm{P}_{2} \mathrm{O}_{5}$ olacak şekilde gübre uygulanmıştır (Sirat ve Sezer, 2013). Ekimle birlikte $\mathrm{P}_{2} 0_{5}$ DAP gübresi olarak, azot uygulaması ise ekim ve sapa kalkma dönemi öncesinde olmak üzere iki eşit dozda uygulanmıştır. Çalışmada sulama yapılmamıştır. Yabancı ot mücadelesi kimyasal olarak yapılmıştır. Deneme alanı toprağı killi tınlı (\% $54.60)$, orta derecede kireç içeren $\left(8.56 \mathrm{~kg} \mathrm{da}^{-1}\right)$, tuzsuz (\% 0.016) organik maddece fakir $(\%$ 1.93) ve alkali (8.13) bir yapıdadır. Bunun yanında besin elementleri bakımından fosfor içeriği orta $(8.57 \mathrm{~kg} \mathrm{da}-1)$ ve potasyum içeriği $\left(47.43 \mathrm{~kg} \mathrm{da}^{-1}\right)$ yüksektir. İklim verileri Çizelge 2'de verilmiştir. Çizelge 2 incelendiğinde tane verimini etkileyen yağış miktarı denemenin üçüncü yılında, birinci ve ikinci y1l ile uzun ylllar ortalamasina göre oldukça yüksek gerçekleşmiştir. Denemenin yürütüldüğü birinci, ikinci ve üçüncü yıl toplam yağış miktarı sirasıyla $535.2,513.6$ ve $687.0 \mathrm{~mm}$ olurken, uzun yıllar yağış toplamı $560.3 \mathrm{~mm}$ olmuştur. Vejetasyon döneminde birinci yıl, ikinci yıl, üçüncü yıl ve uzun yıllar sicaklık ortalaması sirasıyla 9.3, 8.3, 7.9 ve $9.0^{\circ} \mathrm{C}$ olmuştur. Ortalama nispi nem birinci, ikinci, üçüncü yıllarda sırasıyla \% 63.8, 60.7, 68.4 olurken uzun yıllarda \% 68.4 olarak gerçekleşmiştir (Çizelge 2). Denemenin birinci yılında Mart ayının son haftasında görülen sıfırın altındaki ani ve şiddetli sıcaklık düşüşü bitkilerin zarar görmesine neden olmuştur.

Çalışmada bitki boyu, tane verimi, bin tane ağırlığ 1 , hektolitre ağırlığı, kül oranı, yağ, protein ve nişasta içeriği, ADF (asit deterjanda çözünmeyen lif) ve NDF (nötr deterjanda çözünmeyen lif), $\mathrm{K}$ ve $\mathrm{P}$ içerikleri incelenmiştir. Bitki boyu, hektolitre ağırlığı, bin tane ağırlığı, kül oranı, protein oranı, Van Soest ve ark. (1991)'na göre ADF ve NDF değerleri, Ewers Polarimetrik metoda (AACC, 2005) göre nişasta içeriği, "Olsen" yöntemine göre fosfor $(\mathrm{P})$ oranı belirlenmiştir. Potasyum (K) ve Magnezyum ( $\mathrm{Mg}$ ) oranları ise Atomik Absorbsiyon Spektroskopisi ile tespit edilmiştir (Kacar 1994).

Sonuçlar SAS paket istatistik analiz programında yapılmış ve özelliklerin ortalamaları arasındaki karşılaştırmalar Duncan çoklu karşılaştırma testi ile değerlendirilmiştir (SAS, 1998). Çizelgelerde aynı sıra ve sütunlarda aynı harflerle gösterilen değerler arasında 0.01 önem seviyesine göre fark yoktur. 
Çizelge 2. Deneme yıllarına ve uzun yıllara ait iklim verileri*

\begin{tabular}{|c|c|c|c|c|c|c|c|c|c|c|c|}
\hline & Ekim & Kasım & Aralık & Ocak & Şubat & Mart & Nisan & May1s & Haziran & Temmuz & Ort/Top. \\
\hline \multicolumn{12}{|c|}{ Toplam Yağış (mm) } \\
\hline $2012-2013$ & 53.7 & 55.9 & 120.3 & 75.4 & 78.5 & 54.2 & 35.9 & 22.0 & 35.6 & 3.7 & 535.2 \\
\hline 2013-2014 & 22.1 & 36.5 & 25.1 & 58.7 & 17.6 & 116.7 & 31.6 & 121.8 & 79.8 & 3.7 & 513.6 \\
\hline 2014-2015 & 72.6 & 61.3 & 53.3 & 54.5 & 68.0 & 115.3 & 28.0 & 131.6 & 95.3 & 7.1 & 687.0 \\
\hline Uzun Yillar & 42.6 & 63.8 & 76.6 & 65.1 & 61.5 & 62.1 & 69.5 & 62.1 & 42.2 & 14.8 & 560.3 \\
\hline \multicolumn{12}{|c|}{ Ortalama Sicaklık $\left({ }^{\circ} \mathrm{C}\right)$} \\
\hline $2012-2013$ & 12.8 & 6.1 & 2.1 & 0.1 & 3.0 & 5.3 & 9.9 & 16.3 & 18.2 & 19.2 & 9.3 \\
\hline 2013-2014 & 8.6 & 5.5 & -3.0 & 1.3 & 2.7 & 5.2 & 10.8 & 13.6 & 16.8 & 21.8 & 8.3 \\
\hline 2014-2015 & 10.6 & 4.2 & 4.1 & -1.0 & 0.8 & 4.4 & 6.1 & 14.1 & 16.0 & 19.8 & 7.9 \\
\hline Uzun Yillar & 10.2 & 4.2 & 0.0 & -2.0 & -0.9 & 3.0 & 8.3 & 12.9 & 16.8 & 19.8 & 9.0 \\
\hline \multicolumn{12}{|c|}{ Ortalama Nem $(\%)$} \\
\hline $2012-2013$ & 61.7 & 79.8 & 81.2 & 77.6 & 72.4 & 63.8 & 61.3 & 47.8 & 46.1 & 46.6 & 63.8 \\
\hline 2013-2014 & 55.4 & 67.2 & 71.0 & 75.5 & 61.9 & 63.5 & 53.4 & 60.4 & 56.0 & 43.2 & 60.7 \\
\hline 2014-2015 & 69.3 & 70.2 & 77.9 & 76.7 & 73.3 & 69.5 & 61.9 & 59.9 & 71.5 & 54.7 & 68.4 \\
\hline Uzun Yillar & 65.9 & 72.1 & 76.8 & 77.0 & 74.9 & 70.0 & 66.6 & 64.0 & 60.3 & 56.6 & 68.4 \\
\hline
\end{tabular}

*İklim verileri Yozgat Meteoroloji Müdürlüğünden alınmıştır.

\section{Bulgular ve Tartışma}

\subsection{Bitki Boyu ve Tane Verimi}

Bitki boyu bakımından yıllar arasında ve her üç yılda da çeşitler arasında çok önemli fark $(\mathrm{P}<0.01)$ bulunmuştur (Çizelge 3). Ortalama bitki boyu 20122013, 2013-2014 ve 2014-2015 yetiştirme sezonlarında sırasiyla $65.46,82.92$ ve $85.30 \mathrm{~cm}$ olmuştur. Çizelge 2'nin incelenmesinden anlaşılacağı üzere üçüncü yetiştirme sezonunda toplam miktarı diğer sezonlara göre nispeten daha fazla olmuş ve bununda bitki boyunu olumlu yönde etkilediği düşünülmektedir. Çeşitlerin bitki boyu bakımından verdiği tepki yıllara göre farklılık göstermiş olup yıl×çeşit interaksiyonunun önemli olduğu ve çeşitlerin sıralanışında önemli değişiklikler olduğu gözlenmiştir (Çizelge 3). Birinci yıl Aydanhanım, Bülbül-89 ve Zeynel Ağa çeşitleri, ikinci yıl Aydanhanım, Erginel-90, Zeynel Ağa, Larende ve Özdemir-05 çeşitleri, üçüncü yıl ise Aydanhanım,
Tarm-92 ve Erginel-90 çeşitleri en uzun boylu çeşitler olmuş ve istatistiki olarak aynı grupta yer almıştır. Çizelge 3'de görüldüğü gibi yılların ortalamasına göre de çeşitler arasında önemli farklılıklar belirlenmiş ve ortalama bitki boyu $77.89 \mathrm{~cm}$ olmuş, en kısa $67.66 \mathrm{~cm}$ ile Metaxa çeşidinde, en uzun $91.83 \mathrm{~cm}$ ile Aydanhanım çeşidinde ölçülmüştür. Üç y1llık ortalamaya göre Aydanhanım çeşidi uzun bitki boyu ve istikrarlı yapısıyla öne çıkmaktadır. Bitki boyu tarımsal uygulamalara (ekim zamanı, ekim sıklığı, gübreleme gibi), çeşidin genetik yapısına, yă̆ı̧ rejimine ve toprak özelliklerine bağlı olarak değişmektedir (Çölkesen ve ark., 1993). Yapılan çalışmalarda (Doğan ve ark., 2014; Mut ve ark., 2014; Alkan ve Kandemir, 2015; Çöken ve Akman, 2016; Aktaş, 2017; Ergün ve ark., 2017) bitki boyunun 65.8 ile $115.4 \mathrm{~cm}$ arasında değiştiği bildirilmiştir. Bitki boyu, verime dolaylı yoldan etki etmesi nedeniyle tahıllarda üzerinde durulan bir özelliktir (Doğan ve ark., 2014; Mut ve ark., 2014).

Çizelge 3. Arpa çeşitlerinin bitki boyu ve tane verimine ait ortalama değerler

\begin{tabular}{|c|c|c|c|c|c|c|c|c|c|c|c|c|c|c|c|}
\hline \multirow{3}{*}{$\begin{array}{l}\text { Çeşitler } \\
\text { Angela }\end{array}$} & \multicolumn{8}{|c|}{ Bitki boyu $(\mathrm{cm})$} & \multicolumn{7}{|c|}{ Tane verimi $\left(\mathrm{kg} \mathrm{da}^{-1}\right)$} \\
\hline & \multicolumn{2}{|c|}{$2012-13$} & \multicolumn{2}{|c|}{ 2013-14 } & \multicolumn{2}{|c|}{$2014-15$} & \multicolumn{2}{|c|}{ Ortalama } & \multicolumn{2}{|c|}{$2012-13$} & \multicolumn{2}{|c|}{ 2013-14 } & \multicolumn{2}{|c|}{ 2014-15 } & Ortalama \\
\hline & 59.37 & $\mathrm{~d}$ & 88.33 & $\mathrm{ab}$ & 73.46 & fg & 73.72 & de & 222.7 & $\mathrm{ab}$ & 351.0 & $\mathrm{a}$ & 290.0 & $\mathrm{~cd}$ & $287.9 \mathrm{~cd}$ \\
\hline Epona & 61.83 & $\mathrm{~cd}$ & 73.00 & $\mathrm{~d}$ & 76.98 & efg & 70.61 & ef & 302.8 & $\mathrm{a}$ & 331.3 & $a b$ & 270.0 & $\mathrm{~d}$ & 301.4 \\
\hline Erginel-90 & 61.67 & $\mathrm{~cd}$ & 89.33 & $\mathrm{a}$ & 96.92 & $a b$ & 82.64 & $\mathrm{~b}$ & 287.3 & $\mathrm{a}$ & 366.7 & $\mathrm{a}$ & 471.6 & $\mathrm{a}$ & 375.2 \\
\hline Kondrat & 58.10 & $\mathrm{~d}$ & 72.00 & d & 77.52 & efg & 69.21 & ef & 228.3 & $a b$ & 325.0 & $a b$ & 307.5 & bcd & 286.9 \\
\hline Scarpia & 68.77 & bc & 81.00 & $\mathrm{c}$ & 82.34 & def & 77.37 & $\mathrm{~cd}$ & 229.5 & $a b$ & 365.6 & $\mathrm{a}$ & 384.0 & $a b c$ & 326.4 \\
\hline Aydanhanım & 81.00 & $\mathrm{a}$ & 90.67 & $\mathrm{a}$ & 103.82 & $\mathrm{a}$ & 91.83 & $\mathrm{a}$ & 244.9 & $a b$ & 329.2 & $a b$ & 437.5 & $\mathrm{a}$ & 337.2 \\
\hline Bülbül-89 & 79.57 & $\mathrm{a}$ & 81.00 & $\mathrm{c}$ & 83.67 & cde & 81.41 & $\mathrm{bc}$ & 240.7 & $a b$ & 237.5 & $\mathrm{~b}$ & 370.8 & $a-d$ & 283.0 \\
\hline Larende & 58.60 & d & 89.00 & $a b$ & 88.45 & bcd & 78.68 & $\mathrm{bc}$ & 308.9 & $\mathrm{a}$ & 358.3 & $\mathrm{a}$ & 415.0 & $a b$ & 360.8 \\
\hline Metaxa & 60.00 & cd & 71.00 & $\mathrm{~d}$ & 71.98 & $\mathrm{~g}$ & 67.66 & $\mathrm{f}$ & 183.2 & $\mathrm{~b}$ & 272.9 & $a b$ & 380.0 & $a-d$ & 278.7 \\
\hline Özdemir-05 & 58.17 & $\mathrm{~d}$ & 88.33 & $a b$ & 93.38 & $\mathrm{bc}$ & 79.96 & $\mathrm{bc}$ & 262.1 & $a b$ & 325.0 & $a b$ & 390.0 & $a b c$ & 325.7 \\
\hline Sarmat & 64.67 & $\mathrm{~cd}$ & 81.00 & $\mathrm{c}$ & 84.71 & cde & 76.79 & $\mathrm{~cd}$ & 215.7 & $a b$ & 352.1 & $\mathrm{a}$ & 358.8 & $a-d$ & 308.8 \\
\hline Tarm-92 & 63.17 & $\mathrm{~cd}$ & 83.00 & bc & 97.28 & $a b$ & 81.15 & bc & 241.0 & $a b$ & 351.0 & $\mathrm{a}$ & 288.8 & $\mathrm{~cd}$ & 293.6 \\
\hline Zeynel Ağa & 76.07 & $\mathrm{ab}$ & 90.33 & $\mathrm{a}$ & 78.35 & efg & 81.58 & bc & 237.1 & $\mathrm{ab}$ & 353.1 & $\mathrm{a}$ & 411.5 & $\mathrm{ab}$ & 333.9 \\
\hline Ortalama & 65.46 & $\mathrm{c}$ & 82.92 & $\mathrm{~b}$ & 85.30 & $\mathrm{a}$ & 77.8 & & 246.5 & $\mathrm{c}$ & 332.2 & $\mathrm{~b}$ & 367.3 & $\mathrm{a}$ & 315.3 \\
\hline $\mathrm{VK}(\%)$ & 8.4 & & 4.5 & & 6.8 & & 6.5 & & 16.8 & & 16.9 & & 18. & & 19.37 \\
\hline
\end{tabular}


Zira arpa, büyük oranda hayvan beslemede sadece tane amaçlı değil sap, saman ve hasıl yem gibi kaba yem olarak da tüketilen bir tahıldır (Kün, 1996). Öte yandan yetiştiricilik açısından bitki boyunun artması yatmayı arttıracağından istenmeyen bir durumdur.

Tane verimine y1l $(\mathrm{P}<0.01)$ ve çeşitlerin $(\mathrm{P}<0.05)$ istatistiki olarak önemli etkileri olmuştur. 2012-2013, 2013-2014, 2014-2015 yetiştirme sezonlarında ve yılların ortalamasındaki tane verimleri sirasıyla 246.5, $332.2,367.3 \mathrm{~kg}$ ve $315.3 \mathrm{~kg} \mathrm{da}^{-1}$ olmuştur. Denemenin birinci yılında düşen yağış miktarı ikinci yılında düşen yağış miktarından daha fazla olmasına rağmen 30 Mart'ta görülen don olayından dolayı bitkiler zarar görmüş ve birinci yıl tane verimleri daha düşük olmuştur. Çalışmanın üçüncü yılında tane verimlerinin diğer yıllardaki denemelerden yüksek olmasının temel nedeninin bu yılda düşen yağışın daha yüksek olmasından kaynaklandığı düşünülmektedir (Çizelge 2). Yıllar içerisinde çeşitler değerlendirildiğinde birinci yılda çok geniş bir varyasyon olmamakla beraber Larende ve Epona çeşitleri yüksek tane verimiyle, Metaxa çeşidi ise düşük verimiyle dikkat çekmektedir (Çizelge 3). İkinci y1lda Bülbül-89 çeşidindeki verim düşüşü dikkat çekmiș ve söz konuşu bu düşüş 7 çeșide göre istatiksel olarak da önemli bulunmuştur. Bu yılda Erginel-90 çeşidi en yüksek tane verimine sahip olmasına rağmen Bülbül-89 hariç diğer çeşitlerden farklı bulunmamıştır. Üçüncü sezonda çeşitler arasındaki farklılıklar daha belirgin olmuş ve Erginel90, Aydınhanım, Larende ve Zeynel Ağa ilk dört sırada yer almıştır. Üç yılın ortalamasına göre tane verimi en yüksek $375.2 \mathrm{~kg}$ da-1 ile Erginel-90 çeşidinde elde edilmiş bu çeșidi aynı istatistiki grupta yer alan Larende $\left(360.8 \mathrm{~kg} \mathrm{da}^{-1}\right)$, Aydanhanım (337.2 $\left.\mathrm{kg} \mathrm{da}^{-1}\right)$, Zeynel Ağa $\left(333.9 \mathrm{~kg} \mathrm{da}^{-1}\right)$, Özdemir-05 (325.7 kg da-1) ve Scarpia $\left(326.4 \mathrm{~kg} \mathrm{da}^{-1}\right)$ çeşitleri izlemiştir. En düşük tane verimi ise $278.7 \mathrm{~kg} \mathrm{da}^{-1}$ ile Metaxa çeşidinden elde edilmiş, Kondrat, Epona, Angela, Tarm-92 ve Bülbül-89 çeşitleriyle aynı istatistiki grupta yer almıştır. Arpada verimi çeşidin genetik potansiyeli yanında düşen yağış miktarı ve bunun aylara dağılımı, topraktaki nem ve besin maddeleri miktarı, uygulanan yetiștirme teknikleri gibi faktörler belirlemektedir (Mut ve ark., 2014). Yapılan çalışmalarda tane veriminin 407.0 ile $487.0 \mathrm{~kg}$ $\mathrm{da}^{-1}$ (Karahan ve Sabanc1, 2010), 314.9 ile $474.7 \mathrm{~kg} \mathrm{da}^{-1}$ (Mut ve ark.,2014), 307.9 ile $502.1 \mathrm{~kg} \mathrm{da}^{-1}$ (Alkan ve Kandemir, 2015), 218.0 ile $363.0 \mathrm{~kg} \mathrm{da}^{-1}$ (Çöken ve Akman, 2016), 290.0 ile $552.0 \mathrm{~kg} \mathrm{da}^{-1}$ (İmamoğlu ve ark., 2016), 376.9 ile $670.4 \mathrm{~kg} \mathrm{da}^{-1}$ (Kızılgeçi ve ark., 2016), 381.5 ile $525.5 \mathrm{~kg} \mathrm{da}^{-1}$ (Sirat ve Sezer, 2017) ve 605.0 ile $787.0 \mathrm{~kg} \mathrm{da}^{-1}$ (Oral ve ark., 2017) arasında değiştiğini bildirmişlerdir.

\subsection{Hektolitre ve bin tane ağırliğl}

Hektolitre ağırlığının yıllara ve çeşitlere göre istatistiki olarak $\mathrm{P}<0.01$ seviyesinde farklı olduğu belirlenmiştir (Çizelge 4). Hektolitre ağırlığı birinci yıl $61.29 \mathrm{~kg}$, ikinci y1l $62.30 \mathrm{~kg}$ ve üçüncü y1l $64.28 \mathrm{~kg}$ olmuştur. Çizelge 4 incelendiğinde çeşitlerin hektolitre ağırlıklarındaki diziliş yıllara göre değişmiş ve bu bakımdan yıl×çeşit interaksiyonuda istatistiki olarak $\mathrm{P}<0.01$ önem seviyesinde bulunmuştur. 2012-2013 sezonunda Özdemir-05, Metaxa ve Aydınhanım, 20132014 sezonunda Metaxa, Zeynel Ağa, Özdemir-05 ve Aydınhanım, 2014-2015 sezonunda ise Tarm-92 ve Özdemir-05 en yüksek hektolitre ağırlığ sahip olmuşlardır. Üç yılın ortalamasına göre hektolitre ağırlığı en düşük Scarpia çeşidinden, en yüksek ise kg ile Özdemir-05, Metaxa ve Aydınhanım çeşitlerinden elde edilmiş ve ortalama $62.60 \mathrm{~kg}$ olmuştur. En yüksek hektolitre ağırlığına sahip Özdemir-05 çeşidi istatistiki olarak Metaxa ve Aydanhanım çeşitleri ile aynı grupta yer almıştır. Çeşitlerin değişen çevre koşullarına farklı tepki vermesinden dolayı yıl×çeşit etkileşiminin önemli bulunduğu düşünülmektedir. Hektolitre ağırlığının iklim ve çevre koşullarından etkilenmesinin yanında çeşidin altı ya da iki sıralı olmasına göre de değişmektedir. Ayrıca hektolitre ağırlığının tanenin protein içeriği, tanelerdeki homojenlik, endosperm yapısı ve kavuz oranına bağlı olarak çeşitlere ve yetiştirme koşullarına göre değişkenlik gösterdiği bildirilmektedir (Kün, 1996; Mut ve ark., 2014). Yapılan çalışmalarda hektolitre ağırlığının 55.1 ile $76.4 \mathrm{~kg}$ arasında değiştiği bildirilmiştir (Mut ve ark., 2014; Doğan ve ark., 2014; Alkan ve Kandemir, 2015; Çöken ve Akman, 2016; İmamoğlu ve ark., 2016; Kızılgeçi ve ark., 2016; Aydoğan ve ark., 2017; Sirat ve Sezer, 2017).

Üç yıl süreyle yürütülen bu araştırmada bin tane ağırlığının yıllara ve çeşitlere göre çok önemli $(p<0.01)$ derecede değiştiği saptanmıştır (Çizelge 4). 2012-2013, 2013-2014, 2014-2015 yıllarında ve birleşmiş yıllarda bin tane ağırlığı sırasıyla $35.20,39.97,42.57$ ve $39.25 \mathrm{~g}$ olmuştur. Bin tane ağırlığı çeşide göre değişkenlik gösteren bir özellik olsa da çevre koşullarından çok fazla etkilenmektedir. Çalışmanın üçüncü yılında iklim koşullarının daha iyi olması tane dolum periyodunu uzatmış ve bin tane ağırlı̆̆ını arttırmıştır. Özellikle yağışa dayalı koşullarda kurağa daha toleranslı çeşitlerin bin tane ağırlıklarında daha az kayıplar verdiği tespit edilmiştir (Aktaş, 2017). En yüksek bin tane ağırlığına birinci y1l Metaxa, Aydanhanım, Ödemir-05, Zeynel Ağa ve Bülbül-89 çeşitleri, ikinci yıl Metaxa çeşidi, üçüncü yıl ise Metaxa, Sarmat, Aydanhanım, Özdemir05 çeşitleri sahip olmuştur. Yılların ortalamasına göre değerlendirildiğinde Kondrat çeşidinin $(33.0 \mathrm{~g})$ en düşük, Metaxa (45.6 g) çeşidinin en yüksek bin tane ağırlığına sahip olduğu görülmektedir. Arpa çeşitlerinin bin tane ağırlığı bakımından yıllara göre farklılık göstermesi yıl $\times$ çeşit interaksiyonun önemli çıkmasına neden olmuştur. 
Çizelge 4. Arpa çeşitlerinin hektolitre ağırlığı ve tane verimine ait ortalama değerler

\begin{tabular}{|c|c|c|c|c|c|c|c|c|c|c|c|c|c|c|c|c|}
\hline \multirow{3}{*}{$\begin{array}{l}\text { Çeşitler } \\
\text { Angela }\end{array}$} & \multicolumn{8}{|c|}{ Hektolitre Ağırlığ $1(\mathrm{~kg})$} & \multicolumn{8}{|c|}{ Bin tane ağırlığ $1(\mathrm{~g})$} \\
\hline & \multicolumn{2}{|c|}{$2012-13$} & \multicolumn{2}{|c|}{ 2013-14 } & \multicolumn{2}{|c|}{ 2014-15 } & \multicolumn{2}{|c|}{ Ortalama } & \multicolumn{2}{|c|}{$2012-13$} & \multicolumn{2}{|c|}{ 2013-14 } & \multicolumn{2}{|c|}{$2014-15$} & \multicolumn{2}{|c|}{ Ortalama } \\
\hline & 56.79 & $\mathrm{e}$ & 59.23 & $\mathrm{c}$ & 58.35 & f & 58.12 & $\mathrm{e}$ & 32.07 & $\mathrm{e}$ & 35.20 & $\mathrm{~g}$ & 38.19 & $\mathrm{~d}$ & 35.15 & $\mathrm{e}$ \\
\hline Epona & 63.73 & $\mathrm{~d}$ & 68.26 & $\mathrm{c}$ & 63.20 & $\mathrm{~d}$ & 65.06 & $\mathrm{~d}$ & 26.87 & $\mathrm{f}$ & 32.78 & $\mathrm{~h}$ & 39.41 & $\mathrm{~d}$ & 33.02 & $\mathrm{f}$ \\
\hline Erginel-90 & 60.34 & $\mathrm{~d}$ & 61.49 & $\mathrm{bc}$ & 63.20 & d & 61.68 & d & 32.73 & $\mathrm{e}$ & 37.43 & ef & 39.67 & d & 36.61 & $\mathrm{de}$ \\
\hline Kondrat & 57.62 & $\mathrm{e}$ & 61.59 & $\mathrm{bc}$ & 57.65 & $\mathrm{f}$ & 58.95 & $\mathrm{e}$ & 27.83 & $\mathrm{f}$ & 31.41 & $\mathrm{~h}$ & 32.95 & $\mathrm{e}$ & 30.73 & $\mathrm{~g}$ \\
\hline Scarpia & 54.84 & $\mathrm{f}$ & 53.18 & $\mathrm{~d}$ & 60.50 & $\mathrm{e}$ & 56.17 & $\mathrm{f}$ & 33.53 & de & 38.31 & $\mathrm{e}$ & 38.76 & $\mathrm{~d}$ & 36.87 & $\mathrm{~d}$ \\
\hline Aydanhanım & 65.01 & $a b$ & 67.13 & $\mathrm{a}$ & 66.90 & bc & 66.35 & $a b$ & 40.67 & $\mathrm{a}$ & 43.10 & $\mathrm{~cd}$ & 47.49 & $a b c$ & 43.75 & $\mathrm{~b}$ \\
\hline Bülbül-89 & 63.09 & $\mathrm{c}$ & 63.95 & $\mathrm{~b}$ & 66.23 & $\mathrm{c}$ & 64.42 & $\mathrm{c}$ & 40.43 & $\mathrm{a}$ & 42.39 & $\mathrm{~d}$ & 45.00 & bc & 42.61 & $\mathrm{~b}$ \\
\hline Larende & 60.77 & $\mathrm{~d}$ & 59.33 & $\mathrm{c}$ & 66.20 & $\mathrm{c}$ & 62.10 & d & 33.87 & de & 41.65 & d & 44.00 & $\mathrm{c}$ & 39.84 & $\mathrm{c}$ \\
\hline Metaxa & 65.81 & $\mathrm{a}$ & 69.18 & $\mathrm{a}$ & 66.45 & $\mathrm{bc}$ & 67.15 & $\mathrm{a}$ & 39.07 & $a b$ & 48.19 & $\mathrm{a}$ & 49.42 & $\mathrm{a}$ & 45.56 & $\mathrm{a}$ \\
\hline Özdemir-05 & 66.07 & $\mathrm{a}$ & 67.85 & $\mathrm{a}$ & 68.30 & $\mathrm{ab}$ & 67.41 & $\mathrm{a}$ & 40.00 & $\mathrm{a}$ & 42.24 & d & 48.33 & $\mathrm{ab}$ & 43.53 & $\mathrm{~b}$ \\
\hline Sarmat & 57.10 & $\mathrm{e}$ & 54.31 & d & 63.90 & $\mathrm{~d}$ & 58.44 & $\mathrm{e}$ & 35.17 & $\mathrm{~cd}$ & 46.11 & $\mathrm{~b}$ & 48.23 & $a b$ & 43.17 & $\mathrm{~b}$ \\
\hline Tarm-92 & 64.25 & bc & 63.74 & b & 68.75 & $\mathrm{a}$ & 65.58 & $\mathrm{~b}$ & 36.97 & bc & 36.28 & fg & 37.33 & d & 36.86 & $\mathrm{~d}$ \\
\hline Zeynel Ağa & 61.36 & $\mathrm{bc}$ & 60.67 & $\mathrm{a}$ & 66.05 & $\mathrm{c}$ & 62.69 & $\mathrm{~b}$ & 38.40 & $\mathrm{ab}$ & 44.50 & $\mathrm{bc}$ & 44.67 & $\mathrm{bc}$ & 42.52 & $\mathrm{~b}$ \\
\hline Ortalama & 61.29 & $\mathrm{c}$ & 62.30 & $\mathrm{~b}$ & 64.28 & $\mathrm{a}$ & 62.6 & & 35.20 & $\mathrm{c}$ & 39.97 & $\mathrm{~b}$ & 42.57 & $\mathrm{a}$ & 39.2 & \\
\hline VK (\%) & 1.3 & & 2.5 & & 1.6 & & 1.9 & & 3.8 & & 2.7 & & 5.5 & & 4.3 & \\
\hline
\end{tabular}

Bin tane ağırlı̆̆ çevre şartlarından etkilendiği gibi bu özellik bakımından genotipler arasında da çok önemli farklılıklar olduğu ve iki sıralı arpa çeşitlerinin daha yüksek bin tane ağırlığına sahip olduğu yapılan bir çok araştırmada (Mut ve ark., 2014; Alkan ve Kandemir, 2015; Çöken ve Akman, 2016; Aktaş, 2017; Aydoğan ve ark., 2017) ortaya konmuştur.

\subsection{Kül ve yă̆ oranl}

Kül oranının yıl, çeşit ve yıl×çeşit interaksiyonundan istatistiki olarak $\mathrm{P}<0.01$ seviyesinde etkilendiği belirlenmiştir (Çizelge 5). 2012-2013, 2013-2014, 20142015 yetiştirme sezonlarında ve birleşmiş yıllarda kül oranı sırasıyla \% 2.287, 1.904, 1.642 ve 1.944 olmuştur. Kül oranı birinci yıl Metaxa, Sarmat, Kondrat, Epona, Angela, Özdemir-05 ve Zeynel Ağa, ikinci y1l Larende ve Epona çeşitlerinde daha yüksek olmuştur. Üçüncü yıl ise Sarmat çeşidinin kül oranı daha yüksek olmuştur. İklim şartları çeşitlerin yıllardaki kül oranlarında değişimlere neden olmuştur. Çizelge 5'de görüldüğü gibi üç yılın ortalamasına göre, kül oranı en düşük Bülbül-89 (\% 1.771), en yüksek Sarmat (\% 2.097) çeşidinde elde edilmiştir. Sarmat, Epona ve Angela çeșitlerinin kül oranları diğer çeşitlerden daha yüksek olmuştur. Arpa çeşitlerinin kül oranı değerinin yıllara göre değişim göstermesi nedeniyle yıl $\times$ çeşit interaksiyonu önemli olmuştur. Kül miktarı genetik ve çevre faktörleri yanında yetiştirme tekniklerinden de etkilenmektedir. Yapılan çalışmalarda kül içeriğini Brand ve ark. (2003) \% 1.7 ile 2.1 arasında, Ragaee ve ark. (2006) ortalama \% 2.88, Alkan ve Kandemir (2015) $\% 2.04$ ile 2.56 arasında belirlemişlerdir.

Araştırmada elde edilen yağ oranları yönünden deneme yılları arasında Çizelge 5'de görüleceği gibi önemli farklılıklar saptanmıştır. Yağ oranı birinci yıl \% 1.800 , ikinci yıl \% 1.860 ve üçüncü yıl \% 1.920 olmuştur. İklim şartlarından dolayı çeşitlerin farklı yıllardaki yağ oranlarında değiş̧imler gözlemlenmiştir. Çeşitlere ait yağ oranları yıllara göre çok önemli derecede farklılık göstermiş ve yıl $\times$ çeşit interaksiyonuda istatistiki olarak $(\mathrm{P}<0.01)$ çok önemli bulunmuştur. Birinci y1l Scarpia, Tarm-92 ve Bülbül-89 çeşitleri, ikinci yıl Metaxa, Scarpia, Sarmat, Kontrat, Özdemir-05, Tarm-92, Erginel-90, Larende ve Bülbül89 çeşitleri, üçüncü yıl Metaxa, Scarpia, Kondrat ve Erginel-90 çeşitlerinin yağ oranı daha yüksek bulunmuştur.

Çizelge 5. Arpa çeşitlerinin kül ve yağ oranına ait ortalama değerler

\begin{tabular}{|c|c|c|c|c|c|c|c|c|c|c|c|c|c|c|c|}
\hline \multirow{3}{*}{$\begin{array}{l}\text { Çeşitler } \\
\text { Angela }\end{array}$} & \multicolumn{7}{|c|}{ Kül oranı $(\%)$} & \multicolumn{8}{|c|}{ Yağ oran1 $(\%)$} \\
\hline & $2012-13$ & \multicolumn{2}{|c|}{$2013-14$} & \multicolumn{2}{|c|}{ 2014-15 } & \multicolumn{2}{|c|}{ Ortalama } & \multicolumn{2}{|c|}{$2012-13$} & \multicolumn{2}{|c|}{$2013-14$} & \multicolumn{2}{|c|}{$2014-15$} & \multicolumn{2}{|c|}{ Ortalama } \\
\hline & $2.442 \mathrm{ab}$ & 1.945 & b-e & 1.735 & $\mathrm{~b}$ & 2.041 & $a b$ & 1.792 & $\mathrm{bc}$ & 1.823 & $\mathrm{bc}$ & 1.923 & $\mathrm{~cd}$ & 1.846 & $\mathrm{~cd}$ \\
\hline Epona & 2.453 & 2.074 & $a b$ & 1.623 & $\mathrm{~d}$ & 2.050 & $a b$ & 1.713 & $\mathrm{c}$ & 1.313 & $\mathrm{~d}$ & 1.715 & $\mathrm{~g}$ & 1.581 & $\mathrm{f}$ \\
\hline Erginel-90 & 2.129 & 1.994 & bc & 1.721 & $\mathrm{bc}$ & 1.948 & $\mathrm{~cd}$ & 1.811 & bc & 2.073 & a & 2.071 & $\mathrm{a}$ & 1.985 & $\mathrm{~b}$ \\
\hline Kondrat & 2.379 & 2.028 & $a b c$ & 1.593 & $\mathrm{~d}$ & 2.000 & $\mathrm{bc}$ & 1.796 & $\mathrm{bc}$ & 2.060 & $\mathrm{a}$ & 2.005 & $a b$ & 1.954 & $\mathrm{c}$ \\
\hline Scarpia & 2.224 & 1.902 & b-e & 1.620 & $\mathrm{~d}$ & 1.915 & $\mathrm{~cd}$ & 2.116 & $\mathrm{a}$ & 2.073 & a & 2.066 & $\mathrm{a}$ & 2.085 & $\mathrm{a}$ \\
\hline Aydanhanım & 2.135 & 1.882 & $c-f$ & 1.582 & d & 1.866 & $\mathrm{~d}$ & 1.461 & $\mathrm{~d}$ & 1.762 & $\mathrm{bc}$ & 1.815 & ef & 1.680 & $\mathrm{e}$ \\
\hline Bülbül-89 & 2.187 & 1.545 & g & 1.580 & d & 1.771 & $\mathrm{e}$ & 1.941 & $a b$ & 1.925 & $a b$ & 1.946 & bcd & 1.937 & $\mathrm{bc}$ \\
\hline Larende & 2.157 & 2.187 & $\mathrm{a}$ & 1.606 & d & 1.983 & $\mathrm{bc}$ & 1.791 & bc & 1.888 & $a b$ & 1.836 & ef & 1.838 & $\mathrm{~d}$ \\
\hline Metaxa & 2.315 & 1.704 & fg & 1.603 & d & 1.874 & $\mathrm{~d}$ & 1.864 & $\mathrm{bc}$ & 1.888 & $a b$ & 2.014 & $a b$ & 1.922 & bcd \\
\hline Özdemir-05 & 2.274 & 1.905 & b-e & 1.633 & d & 1.937 & $\mathrm{~cd}$ & 1.685 & $\mathrm{~cd}$ & 1.893 & $a b$ & 1.942 & bcd & 1.840 & $\mathrm{~d}$ \\
\hline Sarmat & 2.463 & 1.988 & bcd & 1.839 & $\mathrm{a}$ & 2.097 & $\mathrm{a}$ & 1.784 & $\mathrm{bc}$ & 1.895 & $a b$ & 1.878 & de & 1.852 & $\mathrm{~cd}$ \\
\hline Tarm-92 & 2.250 & 1.794 & ef & 1.580 & $\mathrm{~d}$ & 1.875 & $\mathrm{~d}$ & 1.898 & $a b c$ & 1.929 & $a b$ & 1.956 & $\mathrm{bc}$ & 1.928 & bcd \\
\hline Zeynel Ağa & 2.320 & 1.808 & def & 1.635 & $\mathrm{~cd}$ & 1.921 & $\mathrm{~cd}$ & 1.745 & $\mathrm{bc}$ & 1.662 & $\mathrm{c}$ & 1.791 & $\mathrm{f}$ & 1.733 & $\mathrm{e}$ \\
\hline Ortalama & 2.287 & 1.904 & $\mathrm{~b}$ & 1.642 & c & 1.94 & & 1.800 & $\mathrm{c}$ & 1.860 & $\mathrm{~b}$ & 1.920 & $\mathrm{a}$ & 1.8 & \\
\hline $\mathrm{VK}(\%)$ & 5.27 & 5.6 & & 3.1 & & 5.0 & & 7.3 & & 6.0 & & 2.3 & & 3.8 & \\
\hline
\end{tabular}


Yılların ortalamasına göre ise yağ oranı en düşük olan çeşit Epona (\% 1.581), en yüksek olan ise Scarpia (\% 2.085) çeşidi olmuştur. Scarpia çeşidi bütün yıllarda yüksek yağ oranına sahip olmasıyla dikkat çekmektedir.

Campbell ve ark. (1995) yaptıkları çalışmada yă̆ oranının \% 1.31 ile 3.23 arasında değiştiğini ve yă̆ oranının çeşide, çevreye ve yetiştirme tekniğine bağlı olduğunu bildirmiştir. Yapılan diğer çalışmalarda Brand ve ark. (2003) yağ oranının \% 2.3 ile 2.5 arasında değiş̧tiğini ve Ragaee ve ark. (2006) ortalama yă̆ oranının 2.31 olduğunu bildirmiş̧tir.

\subsection{Protein ve nişasta oranı}

Y1ların ortalaması olarak \% 12.8 olan protein oran1,
2012-2013, 2013-2014, 2014-2015 yetiştirme sezonlarında sirasiyla $\% \quad 14.73,12.57$ ve 11.04 olmuştur. Yağış miktarının diğer yıllara göre daha fazla olduğu üçüncü yıl protein oranı daha düşük olmuştur. Birinci yıl olumsuz iklim koşulları ve yağışın az olması nedeniyle tanelerin küçük kaldığı ve protein oranın diğer yıllara göre yüksek gerçekleştiği düşünülmektedir (Çizelge 2). Yıllar kendi içerisinde değerlendirildiğinde çeşitler arasında önemli farklılıklar saptanmış olup; birinci yıl Özdemir-05 ve Tarm-92 çeşitleri, ikinci yıl Epona ve Angela, üçüncü yıl Sarmat çeşidi protein oranı en yüksek çeşitler olmuştur (Çizelge 6). Çeşitlerin değişen iklim koşullarına farklı tepkiler vermesi istatistiksel olarak da önemli (yıl×çeşit interaksiyonu önemli) bulunmuştur.

Çizelge 6. Arpa çeşitlerinin protein ve nişasta oranına ait ortalama değerler

\begin{tabular}{|c|c|c|c|c|c|c|c|c|c|c|}
\hline \multirow[t]{2}{*}{ Çeşitler } & \multicolumn{5}{|c|}{ Protein oran1 $(\%)$} & \multicolumn{5}{|c|}{ Nișasta oranı (\%) } \\
\hline & $2012-13$ & $2013-14$ & 2014 & 15 & Ortalama & 2012 & -13 & $2013-14$ & 2014-15 & Ortalama \\
\hline Angela & $14.90 \mathrm{bc}$ & $14.13 \mathrm{ab}$ & 11.15 & $\mathrm{c}$ & $13.39 \mathrm{a}$ & 52.33 & $\mathrm{e}$ & $56.50 \mathrm{cde}$ & $63.80 \mathrm{de}$ & $57.54 \mathrm{fg}$ \\
\hline Epona & 14.30 & 14.87 & 10.84 & def & 13.34 & 52.89 & de & $55.35 \mathrm{de}$ & $67.25 \mathrm{ab}$ & 58.50 ef \\
\hline Erginel-90 & 14.68 & $11.36 \mathrm{fg}$ & 11.44 & $\mathrm{~b}$ & 12.49 & 56.15 & $a b$ & 56.73 & $63.89 \mathrm{cde}$ & $58.92 \mathrm{de}$ \\
\hline Kondrat & 14.54 cde & $13.56 \mathrm{bcd}$ & 10.84 & def & 12.98 & 53.98 & b-e & 54.84 & $66.98 \mathrm{ab}$ & $58.60 \mathrm{ef}$ \\
\hline Scarpia & $12.43 \mathrm{f}$ & 11.81 & 10.68 & $\mathrm{f}$ & 11.64 & 57.13 & $\mathrm{a}$ & 57.62 & $65.81 \mathrm{abc}$ & 60.19 bcd \\
\hline Aydanhanım & 14.41 & 13.48 & 10.97 & $\mathrm{~cd}$ & 12.95 & 57.28 & $\mathrm{a}$ & 58.82 & 65.69 a-d & $60.60 \mathrm{~b}$ \\
\hline Bülbül-89 & 14.81 & 11.37 & 10.77 & ef & 12.32 & 57.13 & $\mathrm{a}$ & 62.61 & $67.45 \mathrm{a}$ & $62.40 \mathrm{a}$ \\
\hline Larende & 14.79 & 13.05 & 10.14 & $\mathrm{~g}$ & 12.66 & 55.92 & $a b$ & 56.33 & $66.68 \mathrm{ab}$ & 59.64 b-e \\
\hline Metaxa & 15.34 & 10.82 & 11.11 & $\mathrm{c}$ & 12.42 & 55.22 & $a b c$ & 64.24 & 67.47 & $62.31 \mathrm{a}$ \\
\hline Özde & 16.54 & 12.58 & 11.04 & $\mathrm{~cd}$ & 13.39 & 54.57 & bcd & 58.95 & 65.35 & 59.62 b-e \\
\hline Sarm & 14.22 & 13.73 & 11.92 & $\mathrm{a}$ & 13.29 & 52.34 & $\mathrm{e}$ & 55.98 & 63.12 & $57.15 \mathrm{~g}$ \\
\hline Tarm-92 & 16.45 & 10.70 & 11.04 & $\mathrm{~cd}$ & 12.73 & 55.34 & $a b$ & 59.82 & 66.07 & $60.41 \mathrm{bc}$ \\
\hline Zeynel Ağa & 14.11 & 11.93 & 11.63 & $\mathrm{~b}$ & $12.55 \mathrm{de}$ & 53.14 & cde & $58.87 \mathrm{bc}$ & 65.55 a-d & $59.19 \mathrm{cde}$ \\
\hline Ortalama & $14.73 \mathrm{a}$ & $12.57 \mathrm{~b}$ & 11.04 & $\mathrm{c}$ & 12.78 & 54.88 & $\mathrm{c}$ & $58.21 \mathrm{~b}$ & $65.78 \mathrm{a}$ & 59.62 \\
\hline VK (\%) & 2.13 & 4.82 & 1.4 & & 3.16 & 2.3 & & 2.73 & 1.79 & 2.29 \\
\hline
\end{tabular}

Üç yılın ortalamasına bakıldığında ise Angela ve Özdemir-05 (\% 13.39) çeşitlerinin en yüksek protein oranı sahip oldukları ve bu çeşitlerle Sarmat ve Epona çeşitlerini aynı istatistiki grupta yer aldıkları görülmektedir. Scarpia çeşidi ise protein oranı en düşük çeşit olmuştur.

Arpanın protein oranı beslenme açışından önemli olduğundan yemlik arpalarda yüksek olması istenirken; renk bulanıklığına, lezzetin acılaşmasına ve depo süresini kısalmasına neden olduğu için maltlık arpalarda $\% 12$ 'den düşük olması istenir. Protein oranı yetiştirme teknikleri yanında, çeşidin erkenci ya da geçci, kışlık ya da yazlık, sarı olum döneminin kurak ya da nemli olmasından etkilenir (Kün, 1996; Alkan ve Kandemir, 2015). Yapılan çalışmalarda (Campell ve ark., 1995; Brand ve ark., 2003; Alkan ve Kandemir, 2015; Çöken ve Akman, 2016; İmamoğlu ve ar., 2016; Kızılgeçi ve ark., 2016; Oral ve ark., 2017; Sirat ve Sezer, 2017) protein oranı bakımından farklı sonuçlar elde edilmiş olup değerlerin $\% 9.3$ ile 17.2 arasında değiştiği bildirilmiştir.

Nişasta oranı bakımından yıllar arasında ve çeşitler arasında istatistiksel olarak çok önemli farklılıklar saptanmıştır (Çizelge 6). 2012-2013, 2013-2014, 20142015 yetiştirme sezonlarında nişasta oranı sırasıyla \%
$54.88,58.21$ ve 65.78 olmuştur. En fazla yağış alan üçüncü yılda yağış miktarına paralel olarak nişasta oranı da en yüksek değere sahip olmuştur. Birinci yıl olumsuz iklim koşulları ve yağıșın az olması nedeniyle bin tane ağırlığının azaldığı, tanelerin küçük kaldığı ve nişasta oranın düştüğü belirlenmiştir (Çizelge 2). Çeşitlere ait nişasta oranları incelendiğinde birinci yıl Metaxa, Scarpia, Aydanhanım, Tarm-92, Erginel-90 ve Larende çeşitleri, ikinci yıl Metaxa ve Bülbül-89 çeşitleri, üçüncü yıl ise Metaxa, Kondrat, Epona, Aydanhanım, Tarm-92, Larende, Zeynel Ağa ve Bülbül-89 çeşitlerinin nişasta oranı daha yüksek olduğu ve istatistiki olarak aynı grupta yer aldıkları görülmektedir (Çizelge 6). Üç yılın ortalamasına göre ise en yüksek nişasta oranı \% 62.40 ile Bülbül-89 çeşidinden elde edilmiş olup, Bülbül-89 ile onu izleyen Metaxa (\% 62.31) çeşidi aynı istatistiki grupta yer almıştır. Sarmat çeşidi \% 57.15 ile nişasta oranı bakımından son sırada yer almıştır.

Nişasta tohum ağırlı̆̆ının \% 60'ını oluşturmaktadır. Yemlik arpalarda olmasa da biralık arpalarda önemli bir kalite kriteri olan nişasta oranının \% 55-60'ın altında olması istenmez. Nişastanın yüksek olması ekstrakt verimini arttırır. Dolgun tanelerde protein oranı düşük, nişasta oranı yüksek olmaktadır. Yemlik arpalarda taneler küçük ve kavuz oranı yüksektir. Buna bağlı 
olarak ekstrakt oranı da düşüktür (Kün, 1996; Kızılgeçi ve ark., 2016). Yapılan çalışmalarda nişasta oranının \% 48.1 ile 70.5 (Campell ve ark., 1995, Brand ve ark., 2003, Kızılgeçi ve ark., 2016, Oral ve ark., 2017, Zhang ve Hamaker, 2017) arasında değiştiği bildirilmiştir.

\subsection{Asit deterjanda çözünmeyen lif ve nötr deterjanda çözünmeyen lif oranı}

Asit Deterjanda Çözünmeyen Lif (ADF) değeri yıllar ve çeşitlere göre $\mathrm{P}<0.01$ seviyesinde çok önemli farklılık göstermiştir. ADF değerleri 2012-2013, 20132014 ve 2014-2015 yıllarında sirasiyla \% 7.513, 6.345 ve 6.225 olarak belirlenmiştir. Çalışmada iki sıralı arpa çeşitleri genellikle altı sıralı arpa çeşitlerine göre daha düşük $\mathrm{ADF}$ değerine sahip olmuștur. ADF oranı birinci y1l \% 6.112 ile 8.708, ikinci y1l \% 5.037 ile 7.666, üçüncü yıl ise \% 5.540 ile 7.354 arasında değişmiştir (Çizelge 7). Çeşitlerin değişen iklim koşullarına farklı tepkiler vermesi istatistiksel olarak da önemli (yıl ×çeşit interaksiyonu önemli) bulunmuştur. Çeşitlere ait ADF değeri değerlendirildiğinde en düşük \% 5.898 ile
Metaxa çeşidinden, en yüksek \% 7.523 ile Angela çeşidinden elde edilmiştir. Metaxa, Tarm-92, Bülbül-89 ve Aydanhanım çeşitleri en düşük ADF değerlerine, Angela, Larende, Sarmat ve Epona çeşitleri ise en yüksek ADF değerlerine sahip olmuşlardır.

Nötr Deterjanda Çözünmeyen Lif (NDF) değeri yıllar ve çeşitlere göre $\mathrm{P}<0.01$ seviyesinde çok önemli farklılık göstermiştir. NDF değerleri birinci, ikinci ve üçüncü yıllarda sırasıyla \% 24.69, 24.05 ve 22.19 olarak belirlenmiştir. Çeşitlere ait NDF değerleri yıllara göre çok önemli derecede farklılık göstermiş ve yıl×çeşit interaksiyonuda istatistiki olarak $(\mathrm{P}<0.01)$ çok önemli bulunmuştur. Çeşitlerin ortalamasına göre NDF oranı en düşük \% 22.00 ile Bülbül-89 çeşidinden, en yüksek \% 24.87 ile Epona çeşidinden elde edilmiştir. Sarmat, Kondrat, Epona, Angela ve Larende çeşitleri en yüksek NDF değerlerine sahip olmuş ve aynı istatistiki grupta yer almışlardır. En düşük NDF değeri ise Bülbül-89, Tarm-92 ve Metaxa çeşitlerinden elde edilmiştir. ADF değerinde olduğu gibi NDF değeri de genellikle iki sıralı arpalarda daha düşük bulunmuştur (Çizelge 7).

Çizelge 7. Arpa çeşitlerinin ADF ve NDF oranına ait ortalama değerler

\begin{tabular}{|c|c|c|c|c|c|c|c|c|c|c|c|c|c|}
\hline \multirow[t]{2}{*}{ Çeşitler } & \multicolumn{5}{|c|}{ ADF oran1 (\%) } & \multicolumn{8}{|c|}{ NDF oran $1(\%)$} \\
\hline & $2012-13$ & $2013-14$ & 2014 & -15 & Ortalama & 2012 & & 2013- & & 2014 & & Ortalan & \\
\hline Epona & 8.708 a & $6.396 \mathrm{bc}$ & 6.310 & bcd & 7.138 abc & 26.54 & $\mathrm{a}$ & 25.59 & $\mathrm{a}$ & 22.48 & $a-d$ & 24.87 & $\mathrm{a}$ \\
\hline Angela & $8.608 \mathrm{a}$ & 6.608 & 7.354 & $\mathrm{a}$ & 7.523 & 26.10 & $\mathrm{a}$ & 24.73 & $a b$ & 23.06 & $a b$ & 24.63 & a \\
\hline Erginel-90 & $6.436 \mathrm{de}$ & 6.981 & 6.265 & bcd & 6.561 & 23.20 & $\mathrm{e}$ & 24.12 & bc & 22.52 & $a-d$ & 23.28 & $\mathrm{~cd}$ \\
\hline Kondrat & $8.185 \mathrm{ab}$ & 5.927 & 6.236 & b-e & 6.783 & 25.70 & $a b c$ & 25.28 & $a b$ & 22.08 & bcd & 24.35 & $a b$ \\
\hline Scarpia & $8.009 \mathrm{ab}$ & 6.702 & 6.407 & $\mathrm{bc}$ & 7.039 & 23.94 & de & 24.47 & $a b$ & 21.99 & b-e & 23.47 & $\mathrm{c}$ \\
\hline Aydanhanım & 6.708 cde & 6.329 & 5.631 & de & 6.223 & 23.69 & de & 24.79 & $a b$ & 22.12 & bcd & 23.53 & $\mathrm{c}$ \\
\hline Bülbül-89 & 6.943 & 5.331 & 5.933 & cde & 6.069 & 23.59 & de & 21.57 & $\mathrm{~d}$ & 20.83 & $\mathrm{e}$ & 22.00 & $\mathrm{e}$ \\
\hline Larende & 8.215 & 7.666 & 6.258 & b-e & 7.380 & 25.75 & $a b$ & 25.14 & $a b$ & 22.64 & $a b c$ & 24.51 & $\mathrm{a}$ \\
\hline Metaxa & $7.117 \mathrm{~cd}$ & 5.037 & 5.540 & $\mathrm{e}$ & $5.898 \mathrm{~g}$ & 24.60 & bcd & 22.04 & d & 21.44 & de & 22.69 & de \\
\hline Özdemir-05 & $6.550 \mathrm{de}$ & 6.920 & 6.230 & $b-e$ & $6.567 \mathrm{def}$ & 24.33 & de & 24.82 & $a b$ & 21.90 & cde & 23.68 & $\mathrm{bc}$ \\
\hline Sarmat & 8.566 a & 6.169 & 6.725 & $a b$ & 7.153 & 25.67 & $a b c$ & 24.70 & $a b$ & 23.50 & $\mathrm{a}$ & 24.62 & $\mathrm{a}$ \\
\hline Tarm-92 & 6.112 & $6.262 \mathrm{bcd}$ & 5.652 & de & 6.009 & 23.52 & de & 22.43 & d & 21.75 & cde & 22.57 & de \\
\hline Zeynel Ağa & $7.512 \mathrm{bc}$ & $6.161 \mathrm{bcd}$ & 6.388 & $\mathrm{bc}$ & 6.687 cde & 24.42 & cde & 22.97 & $\mathrm{~cd}$ & 22.10 & bcd & 23.16 & $\mathrm{~cd}$ \\
\hline Ortalama & $7.513 \mathrm{a}$ & 6.345 & 6.225 & $\mathrm{~b}$ & 6.695 & 24.69 & & 24.05 & $\mathrm{~b}$ & 22.19 & $\mathrm{c}$ & 23.64 & \\
\hline VK $(\%)$ & 6.65 & 9.44 & 6.6 & & 7.62 & 3.1 & & 3.63 & & 3.2 & & 3.32 & \\
\hline
\end{tabular}

Arpa tanesi, \% 19-21 NDF ve \% 52-73 nişasta içerir. Bununla birlikte besin komposizyonu coğrafik koşullara, yetiştirildiği ekolojiye ve yıllara, iki ya da altı sıralı, yemlik ya da maltlık olma durumuna ve ekim zamanına göre önemli değișkenlik göstermektedir (Hussey, 2012). Yemin sindirilebilirliğini ADF ve NDF değeri belirlemektedir (Van soest, 1991). ADF yemin sindirilebilirliği ve hayvanın enerji alımını, NDF ise hayvanın yem alımına doğrudan etkili olan özelliklerdir. Yemde ADF değerinin yüksek olması yemlerin sindirilebilirliği ve enerji değerini düşürür (Kutlu, 2008; Mut ve ark., 2017). Yapılan çalışmalarda ADF ve NDF oranını sirasiyla Campell ve ark. (1995) \% 4.5 ile 8.6 ve $\% 11.5$ ile 20.2, Brand ve ark. (2003) \% 2.6 ile 9.2 ve 16.6 ile 28.9, Alkan ve Kandemir (2015) \% 6.53 ile 9.07 ve \% 19.8 ile 26.6, Alijosius ve ark. (2016) \% 5.82 ile 7.46 ve \% 13.07 ile 24.15 arasında değiştiğini bildirmişlerdir.

\subsection{Potasyum, fosfor ve magnezyum içeriği}

Potasyum $(\mathrm{K})$, fosfor $(\mathrm{P})$ ve magnezyum $(\mathrm{Mg})$ değeri yıllar ve çeşitlere göre $\mathrm{P}<0.01$ seviyesinde çok önemli farklılık göstermiştir. Yılların ortalaması olarak birinci, ikinci ve üçüncü yıllarda $\mathrm{K}$ içeriği sırasıyla \% $0.760,0.577$ ve 0.579 olarak belirlenmiştir. Birinci yıl Metaxa, Sarmat, Kondrat, Epona, Angela, Özdemir-05, Tarm-92 ve Larende çeşitleri, ikinci yıl Epona ve Larende çeşitleri, üçüncü yıl ise Sarmat ve Zeynel Ağa çeşitleri $\mathrm{K}$ içeriği en yüksek çeşitler olmuş ve aynı istatistiki grupta yer almıştır. Çeşitlerin $\mathrm{K}$ içeriği en düşük \% 0.600 ile Scarpia çeşidinden, en yüksek \% 0.692 ile Epona çeşidinden elde edilmiştir. Epona çeşidi ile birlikte Angela ve Sarmat çeşitlerinin potasyum içerikleri daha fazla bulunmuş ve aynı grupta yer almışlardır (Çizelge 8).

$\mathrm{P}$ içeriği birinci, ikinci ve üçüncü yıllarda sırasıyla 
\% 0.446, 0.396 ve 0.384 olarak belirlenmiştir. Birinci y1l Özdemir-05 ve Tarm-92 çeşitleri, ikinci yıl Sarmat, Angela ve Larende çeşitleri, üçüncü yıl ise Sarmat, Angela ve Erginel-90 çeşitleri $P$ içeriği en yüksek çeşitler olmuş ve aynı istatistiki grupta yer almıştır. Üç yılın ortalamasına göre çeşitlerin $\mathrm{P}$ içeriği en düşük \% 0.399 ile Scarpia ve Bülbül-89 çeşidinden, en yüksek \% 0.425 ile Angela çeşidinden elde edilmiştir. Sarmat çeşidi de en

Çizelge 8. Arpa çeşitlerinin $\mathrm{K}$ ve $\mathrm{P}$ içeriğine ait ortalama değerler

\begin{tabular}{|c|c|c|c|c|c|c|c|c|c|}
\hline \multirow[t]{2}{*}{ Çeşitler } & \multicolumn{5}{|c|}{ K içeriği (\%) } & \multicolumn{4}{|c|}{ P içeriği (\%) } \\
\hline & $2012-13$ & 2013-14 & 2014 & -15 & Ortalama & $2012-13$ & 2013-14 & 2014-15 & Ortalama \\
\hline Angela & $0.803 \mathrm{ab}$ & $0.627 \quad b c$ & 0.605 & $\mathrm{~b}$ & $0.678 \mathrm{ab}$ & $0.454 \quad b c$ & $0.425 \quad \mathrm{a}$ & 0.396 a & $0.425 \mathrm{a}$ \\
\hline Epona & 0.773 abc & 0.705 & 0.597 & $\mathrm{bc}$ & 0.692 & 0.436 & 0.415 & 0.381 & $11 \mathrm{~cd}$ \\
\hline Erginel-90 & 0.742 & 0.536 & 0.597 & bc & 0.625 & 0.438 & 0.392 & 0.396 & $09 \mathrm{~cd}$ \\
\hline Kon & 0.774 & 0.562 & 0.565 & def & 0.634 & 0.449 & 0.406 & 0.380 & $0.412 \mathrm{~cd}$ \\
\hline Scar & 0.705 & 0.530 & 0.566 & def & 0.600 & 0.423 & 0.393 & 0.382 & $0.399 \mathrm{e}$ \\
\hline & .761 & 0.624 & 0.542 & $\mathrm{fg}$ & 0.642 & 0.436 & 0.399 & 0.378 & $04 \mathrm{de}$ \\
\hline & 760 & 0.489 & 0.559 & efg & 0.603 & 0.453 & 0.373 & 0.371 & 9 e \\
\hline & $a b c$ & 0.664 & 0.540 & $\mathrm{fg}$ & 0.660 & 0.447 & 0.411 & 0.372 & $+10 \mathrm{~cd}$ \\
\hline & 0.780 & 0.528 & 0.589 & bcd & 0.632 & 0.449 & 0.367 & 0.382 & $400 \mathrm{e}$ \\
\hline mir-05 & 0.805 & 0.591 & 0.579 & cde & 0.658 & 0.458 & 0.401 & 0.388 & 116 bc \\
\hline & 0.773 & 0.607 & 0.635 & $\mathrm{a}$ & 0.671 & 0.444 & 0.418 & 0.399 & $0.420 \mathrm{ab}$ \\
\hline & 807 & 0.496 & 0.537 & $\mathrm{~g}$ & 0.613 & 0.468 & 0.381 & 0.379 & $0.409 \mathrm{~cd}$ \\
\hline Zeynel Ağa & $0.734 \mathrm{~cd}$ & 0.539 & 0.610 & $a b$ & $0.628 \mathrm{de}$ & $0.441 \mathrm{~cd}$ & 0.373 & $0.385 \mathrm{bc}$ & $0.400 \mathrm{e}$ \\
\hline Ortalama & 0.760 & 0.577 & 0.579 & b & 0.641 & 0.446 a & 0.396 & 0.384 & 0.409 \\
\hline $\mathrm{VK}(\%)$ & 3.58 & 5.11 & 2.7 & & 3.90 & 1.85 & 2.62 & 1.09 & 1.96 \\
\hline
\end{tabular}

Çizelge 9. Arpa çeşitlerinin Mg değerine ait ortalama değerler

\begin{tabular}{|c|c|c|c|c|c|c|c|c|}
\hline \multirow{3}{*}{$\begin{array}{l}\text { Çeşitler } \\
\text { Angela }\end{array}$} & \multicolumn{8}{|c|}{ Mg içeriği (\%) } \\
\hline & \multicolumn{2}{|c|}{$2012-13$} & \multicolumn{2}{|c|}{ 2013-14 } & \multicolumn{2}{|c|}{ 2014-15 } & \multicolumn{2}{|c|}{ Ortalama } \\
\hline & 0.193 & $a b$ & 0.173 & $\mathrm{a}$ & 0.160 & $\mathrm{ab}$ & 0.175 & $\mathrm{a}$ \\
\hline Epona & 0.186 & $\mathrm{bc}$ & 0.174 & $\mathrm{a}$ & 0.149 & cde & 0.170 & $\mathrm{bc}$ \\
\hline Erginel-90 & 0.180 & $\mathrm{c}$ & 0.152 & $\mathrm{~cd}$ & 0.156 & $a b c$ & 0.162 & $\mathrm{e}$ \\
\hline Kondrat & 0.192 & $a b$ & 0.165 & $a b$ & 0.149 & cde & 0.168 & bcd \\
\hline Scarpia & 0.167 & $\mathrm{~d}$ & 0.149 & de & 0.150 & cde & 0.156 & $\mathrm{f}$ \\
\hline Aydanhanım & 0.180 & $\mathrm{c}$ & 0.161 & $\mathrm{bc}$ & 0.145 & $\mathrm{e}$ & 0.162 & $\mathrm{e}$ \\
\hline Bülbül-89 & 0.188 & $\mathrm{bc}$ & 0.135 & $\mathrm{f}$ & 0.133 & $\mathrm{f}$ & 0.152 & $\mathrm{f}$ \\
\hline Larende & 0.193 & $a b$ & 0.172 & $\mathrm{a}$ & 0.147 & de & 0.171 & $a b$ \\
\hline Metaxa & 0.194 & $a b$ & 0.138 & $\mathrm{f}$ & 0.153 & b-e & 0.162 & $\mathrm{e}$ \\
\hline Özdemir-05 & 0.197 & $\mathrm{a}$ & 0.160 & bc & 0.155 & $a-d$ & 0.171 & $a b$ \\
\hline Sarmat & 0.181 & $\mathrm{c}$ & 0.172 & $\mathrm{a}$ & 0.163 & $\mathrm{a}$ & 0.172 & $a b$ \\
\hline Zeynel Ağa & 0.186 & $\mathrm{bc}$ & 0.148 & de & 0.159 & $a b$ & 0.165 & cde \\
\hline Ortalama & 0.188 & $\mathrm{a}$ & 0.157 & $\mathrm{~b}$ & 0.152 & $\mathrm{c}$ & 0.1 & \\
\hline VK $(\%)$ & \multicolumn{2}{|c|}{ Şub.86 } & \multicolumn{2}{|c|}{ Mar.73 } & \multicolumn{2}{|c|}{ Mar.34 } & \multicolumn{2}{|c|}{ Mar.29 } \\
\hline
\end{tabular}

yüksek P içeriğine sahip Angela çeşidiyle aynı istatistiki grupta yer almıştır (Çizelge 8). Mg içeriği birinci, ikinci ve üçüncü yıllarda sirasılyla \% $0.188,0.157$ ve 0.152 olarak belirlenmiştir.

Birinci y1l Metaxa, Kondrat, Angela, Özdemir-05, Tarm-92 ve Larende çeşitleri, ikinci y1l Sarmat, Kondrat, Epona, Angela ve Larende çeşitleri, üçüncü yıl ise Sarmat, Angela, Özdemir-05, Erginel-90 ve Zeynel Ağa çeşitleri Mg içeriği en yüksek çeşitler olmuş ve aynı istatistiki grupta yer almıştır.

Yılların ortalamasına göre $\mathrm{Mg}$ içeriği en düşük \% 0.152 ile Bülbül-89 çeşidinden, en yüksek \% 0.175 ile Angela çeşidinden elde edilmiştir. Angela ve Sarmat çeşidi aynı istatistiki grupta yer almıştır (Çizelge
9).Çeşitlere ait $\mathrm{K}, \mathrm{P}$ ve $\mathrm{Mg}$ içeriği yıllara göre çok önemli derecede farklılık göstermiş ve yıl×çeşit interaksiyonuda istatistiki olarak $(\mathrm{P}<0.01)$ önemli bulunmuştur. Sönmez ve Yılmaz (2000)'ın 1994 ve 1995 yıllarında yaptıkları çalışmada sırasıyla ortalama $\mathrm{K}$ içeriğini \% 0.29 ve 0.31 , P içeriğini \% 0.24 ve 0.26 , $\mathrm{Mg}$ içeriğini \% 0.08 ve 0.09 olarak belirlemişlerdir. Yapılan diğer çalışmalarda Demirbaş (2005) ortalama K içeriğini \% 2.51, P içeriğini \% 0.27 ve $\mathrm{Mg}$ içeriğini \% 0.24, Ragaee ve ark. (2006) ortalama K içeriğini \% $0.457, \mathrm{P}$ içeriğini \% 0.457 ve $\mathrm{Mg}$ içeriğini \% 0.197 olarak bildirmişlerdir. Alkan ve Kandemir (2015) 26 arpa çeşidinde yaptıkları çalışmada $\mathrm{K}$ içeriğinin \% 0.372 ile 0.461 , P içeriğinin \% 0.269 ile 0.389 ve $\mathrm{Mg}$ içeriğinin 0.116 ile 0.144 arasında değiştiğini 
bildirmişlerdir.

\subsection{Incelenen özellikler arasındaki ilişkiler}

Çeşitlerin incelenen özellikleri arasındaki ilişkiler Çizelge 10'da verilmiştir. Tane verimi ile bitki boyu arasında olumlu ve önemli ilişki belirlenmiştir. Hektolitre ağırlığı ile nişasta oranı arasında olumlu ve önemli, ADF oranı ile ise önemli ve olumsuz ilişki belirlenmiştir. Kül oranı ile $\mathrm{ADF}, \mathrm{NDF}, \mathrm{K}$ ve $\mathrm{Mg}$ arasında olumlu ve çok önemli, protein oranı ile önemli ve olumlu, nişasta oranı ile ise çok önemli ve olumsuz ilişki belirlenmiştir. Yağ oranı ile protein oranı ve $\mathrm{K}$ içeriği arasında önemli ve olumsuz ilişki belirlenmiştir. Protein oranı ile $\mathrm{K}, \mathrm{P}$ ve $\mathrm{Mg}$ içeriği arasında olumlu ve çok önemli, NDF ile olumlu ve önemli, nişasta oranı arasında olumsuz ve önemli ilişki belirlenmiştir. Nişasta oranı ile $\mathrm{ADF}, \mathrm{NDF}, \mathrm{P}$ ve $\mathrm{Mg}$ içeriği arasında olumsuz ve çok önemli, potasyum içeriği ile olumsuz ve önemli ilişki belirlenmiştir. ADF ile NDF özelliklerinin hem birbiriyle hem de $\mathrm{K}, \mathrm{P}$ ve $\mathrm{Mg}$ içerikleri ile olumlu ve çok önemli ilişki gösterdiği tespit edilmiştir. K, P ve Mg içerikleri arasında olumlu ve önemli ilişki belirlenmiştir. Kuru tarım yapılan bölgelerde yüksek sıcaklıklar ve yetersiz yağış nedeni ile tane verimi ve kalite özelliklerinin birbirleriyle olan ilişkileri değişim gösterebilmektedir (Mut ve ark., 2010). Öztürk ve ark. (2007) yaptıkları çalışmada, tane verimi ile bin tane ağırlığ̊ $\left(\mathrm{r}=0,412^{* *}\right)$ arasında olumlu ve çok önemli; bitki boyu ile bin tane ağırlığı $\left(\mathrm{r}=-0,475^{* *}\right)$ arasında olumsuz ve çok önemli; hektolitre ağırlığı ile ham protein oranı $\left(\mathrm{r}=-0,285^{*}\right)$ ile olumsuz ve önemli; bin tane ağırlığı ile hektolitre ağırlığı $(\mathrm{r}=0,564 * *)$ arasında olumlu ve çok önemli ilişki belirlemişlerdir. Kızılgeçi ve ark. (2016) yaptıkları çalışmada Diyarbakır lokasyonunda bin tane ağırlığ 1 ile protein oranı $(0.392 *)$ arasında olumlu ve önemli, nişasta oranı ile ise ($0.543 * *)$ olumsuz ve çok önemli; protein oranı ile hektolitre ağırlığı $\left(0.605^{* *}\right)$ arasında olumlu ve çok önemli ilişki belirlemiştir. Mardin lokasyonunda ise protein oranı ile nişasta oranı $(-0.586 * *)$ arasında olumsuz ve çok önemli; hektolitre ağırlı̆̆ı ile nişasta oranı $(0.468 * *)$ arasında olumlu ve çok önemli ilişki olduğunu bildirmişlerdir.

Çizelge 10. Özellikler arasında korelasyon katsayıları

\begin{tabular}{|c|c|c|c|c|c|c|c|c|c|c|c|c|}
\hline & TV & BB & BTA & $\mathrm{HA}$ & $\mathrm{KO}$ & $\mathrm{YO}$ & $\mathrm{PO}$ & $\mathrm{NO}$ & $\mathrm{ADF}$ & NDF & $\mathrm{K}$ & $\mathrm{P}$ \\
\hline BB & $0.569^{*}$ & & & & & & & & & & & \\
\hline BTA & 0.098 & 0.397 & & & & & & & & & & \\
\hline HA & -0.061 & 0.229 & 0.470 & & & & & & & & & \\
\hline $\mathrm{KO}$ & 0.073 & -0.440 & -0.432 & -0.501 & & & & & & & & \\
\hline YO & -0.043 & -0.135 & -0.097 & -0.436 & -0.271 & & & & & & & \\
\hline PO & -0.146 & -0.099 & -0.098 & 0.184 & $0.596^{*}$ & $-0.628^{*}$ & & & & & & \\
\hline $\mathrm{NO}$ & -0.186 & 0.176 & 0.472 & $0.569^{*}$ & $-0.920^{* *}$ & 0.240 & $-0.602^{*}$ & & & & & \\
\hline $\mathrm{ADF}$ & 0.242 & -0.267 & -0.428 & $-0.683^{*}$ & $0.820^{* *}$ & -0.150 & 0.323 & $-0.795^{* *}$ & & & & \\
\hline NDF & 0.135 & -0.350 & -0.466 & -0.438 & $0.925^{* *}$ & -0.392 & $0.603^{*}$ & $-0.829^{* *}$ & $0.860^{* * *}$ & & & \\
\hline $\mathrm{K}$ & -0.014 & -0.297 & -0.139 & 0.014 & $0.786^{* *}$ & $-0.678^{*}$ & $0.837^{* *}$ & $-0.655^{*}$ & $0.620^{*}$ & $0.824^{* *}$ & & \\
\hline $\mathrm{P}$ & -0.078 & -0.224 & -0.318 & -0.281 & $0.770^{* *}$ & -0.171 & $0.808^{* *}$ & $-0.792^{* *}$ & $0.606^{*}$ & $0.701^{* *}$ & $0.740^{* *}$ & \\
\hline $\mathrm{Mg}$ & 0.018 & -0.310 & -0.236 & -0.116 & $0.824^{* * *}$ & -0.430 & $0.826^{* *}$ & $-0.768^{* *}$ & $0.629^{*}$ & $0.796^{\text {*** }}$ & $0.854^{* *}$ & $0.858^{* *}$ \\
\hline
\end{tabular}

${ }^{*} \mathrm{p}<0.05$ ve ${ }^{* *} \mathrm{p}<0.01$ düzeyinde önemlidir. TV= Tane verimi (kg da-1 ), BB= Bitki boyu (cm), BTA= Bin tane ağırlığ $(\mathrm{g}), \mathrm{HA}=$ Hektolitre ağırlığı, $\mathrm{KO}=\mathrm{Kül}$ oranı $(\%), \mathrm{YO}=\mathrm{Yağ}$ oranı $(\%), \mathrm{PO}=$ Protein oranı $(\%), \mathrm{NO}=$ Nişasta oranı $(\%), \mathrm{ADF}=$ Asit deterjanda çözünmeyen lif $(\%)$, $\mathrm{NDF}=$ Nötr deterjanda çözünmeyen lif (\%), $\mathrm{K}=$ =Potasyum $(\%), \mathrm{P}=$ Fosfor $(\%)$ ve $\mathrm{Mg}=$ magnezyum $(\%)$

\section{Sonuç}

Yozgat koşullarında 2012-2013, 2013-2014 ve 2014-2015 yetiştirme sezonlarında 3 yıl süreyle yürütülen çalışmada; incelenen özellikler bakımından önemli farklılıklar belirlenmiştir. En yüksek tane verimleri Erginel-90 (375.2 $\left.\mathrm{kg} \mathrm{da}^{-1}\right)$, Larende $(360.8 \mathrm{~kg}$ $\left.\mathrm{da}^{-1}\right)$, Aydanhanım (337.2 kg da $\left.{ }^{-1}\right)$, Zeynel Ağa $(333.9$ $\left.\mathrm{kg} \mathrm{da}^{-1}\right)$, Özdemir-05 (325.7 kg da $\left.{ }^{-1}\right)$ ve Scarpia (326.4 $\mathrm{kg} \mathrm{da}^{-1}$ ) çeşitlerinden elde edilmiştir. Ancak arpa için verim tek başına yeterli bir kriter değildir. Kullanım amacına göre bazı özelliklerinde istenilen seviyede olması gerekir. Havyan yemi olarak yüksek tane verimi yanında protein ve bazı minerallerce zengin, sindirilme ve enerji değeri yüksek, belirli oranda kavuz içeren arpalar tercih edilirken, bira ve malt sanayinde ise homojen taneli, kavuz oranı ve protein oranı düşük, nişasta oranı, bin tane ağırlığı ve hektolitre ağırlığı yüksek arpalar tercih edilmektedir. Aydanhanım çeşidi yüksek tane verimi yanında bitki boyu, hektolitre ağırlığı, bin tane ağırlığı ve nişasta içeriği bakımından öne çıkan çeşit olmuştur. Ayrıca, Larende ve Özdemir05 çeşitleri hem verim hem de bazı kalite özellikleri bakımından genel ortalamanın üstünde değerlere sahip olmuştur.

\section{Kaynaklar}

AACC, American Association of Cereal Chemists., 2005. Approved Methods of the AACC (11th ed.). St. Paul, USA.

Aktaş, H., 2017. Türkiye'de yoğun ekim alanına sahip bazı arpa (Hordeum vulgare L.) çeşitlerinin destek sulamalı ve yağışa dayalı koşullarda değerlendirilmesi. Tekirdağ Ziraat Fakültesi Dergisi. 14 (03): 86-97.

Alkan, F. R., Kandemir, N., 2015. Tokak yerel arpa çeşidi içinden seçilen saf hatların bazı gıda, yem ve tarımsal özellikler bakımından varyasyonları. Tarla 
Bitkileri Merkez Araştırma Enstitüsü Dergisi, 24 (2):124-139.

Alijošius S., Švirmickas G. J., Bliznikas S., Gružauskas R., Šašytè V., Racevičiūtè-Stupelienè A., Kliševičiūtè V., Daukšienė A., 2016. Grain chemical composition of different varieties of winter cereals Zemdirbyste-Agriculture, 103 (3): 273-280. doi: 10.13080/z-a.2016.103.035

Aydoğan, S., Şahin, M., Göçmen Akçacık, A., Demir, B., Hamzaoğlu, S., Kara, İ., 2017. Arpa genotiplerinin farklı lokasyonlardaki kalite özelliklerinin değerlendirilmesi. Selçuk Tarım ve G1da Dergisi, 31 (2): 8-13.

doi:10.15316/SJAFS.2017.13

Brand, T.S., Cruywagen, C.W., Brandt, D.A., Viljoen, M., Burger, W.W., 2003. Variation in the chemical composition, physical characteristics and energy values of cereal grains produced in the western cape area of South Africa. South African Journal of Animal Science, 33(2): 117-126. doi:10.4314/sajas.v33i2.3765

Campbell, L. D., Boila, R. J., Stothers, S. C., 1995. Variation in the chemical composition and test weight of barley and wheat grain grown at selected locations throughout Manitoba. Can. J. Anim. Sci. $75 \quad$ (2): 239-246, https://doi.org/10.4141/cjas95-035

Çöken, İ., Akman, Z., 2016. Isparta ekolojik koşullarında bazı arpa (Hordeum vulgare L.) çeşitlerinin verim ve kalite özelliklerinin belirlenmesi. Süleyman Demirel Üniversitesi Fen Bilimleri Enstitüsü Dergisi, 20(1): 91-97. doi: 10.19113/sdufbed.23066

Çölkesen, M., 1993. Buğday ve arpada kalitenin belirlenmesi. Harran Üniversitesi Ziraat Fakültesi Dergisi, 4(1), 115-128.

Demirbaş, A., 2005. B-glucan and mineral nutrient contents of cereals grown in Turkey. Food Chemistry, 90: 773-777. doi: 10.1016/j.foodchem.2004.06.003

Doğan, Y., Kendal, E., Karahan, T., Çiftçi, V., 2014. Diyarbakır Koşullarında Bazı Arpa Genotiplerinde Verim ve Bazı Kalite Özelliklerinin Belirlenmesi. JAFAG, 31(2): 31-40. doi: 10.13002/jafag331

Ergün, N., Aydoğan, S., Sayım, İ., Karakaya, A., Oğuz, A.Ç., 2017. Arpa (Hordeum vulgare L.) Köy Çeşitlerinde Tane Verimi ve Bazı Tarımsal Özelliklerin İncelenmesi. Tarla Bitkileri Merkez Araştırma Enstitüsü Dergisi, 26(2), 180-189. doi: 10.21566/tarbitderg.366381

FAO, 2017. FAO Production Yearbook. Food and Agriculture Organization of United Nations, Rome. http://www.faostat.fao.org/ [Erişim tarihi: 8 Ekim 2018].

Gou T. R., Zhang G. P., Zhou M. X., Wu F. B. and Chen J. X., 2003. Genotypic difference in plant growth and mineral composition in barley under aluminum stres. Agricultural Sciences in China, 2 (5): 494-501.
Hussey, Erin M., 2012. Nutrient mass balance and performance of feedlot cattle fed barley based diets in large pens in western. Thesis in Masters, Theses and Dissertations in Animal Science. 49, Canada.

İmamoğlu, A., Pelit, S., Sarı, N., Buyukkileci, C., Y1ldı, Ö., 2016. Ege bölgesi sahil kuşağına uyumlu arpa (Hordeum vulgare L.) çeşit ve genotiplerinin verim ve bazı kalite özelliklerinin belirlenmesi. Tarla Bitkileri Merkez Araştırma Enstitüsü Dergisi, 25 (Özel say1-1): 141-145. doi: 10.21566/tarbitderg. 280310

Kaçar, B., 1994. Bitki ve Toprağın Kimyasal Analizleri: III, Toprak Analizleri, Ankara Üniversitesi, Ziraat Fakültesi, Eğitim, Araştırma ve Geliştirme Vakfı Yayınları No:3, Ankara.

Karahan, T., Sabanc1, C. O., 2010. Güneydoğu Anadolu ekolojik koşullarında bazı arpa (Hordeum vulgare L.) çeşitlerinin verim ve verim öğelerinin belirlenmesi. Batı Akdeniz Tarımsal Araştırma Enstitüsü Derim Dergisi, 27(1):1-11

Kızılgeçi, F., Yıldırım, M., Albayrak, Ö., Akıncı, C,. 2016. Bazı arpa genotiplerinin Diyarbakır ve Mardin koşullarında verim ve kalite parametrelerinin incelenmesi. Iğdır Üniversitesi Fen Bilimleri Enstitüsü Dergisi, 6(3):161-169. doi: 10.21597/jist.2016321851

Kutlu H. R., 2008. Yem değerlendirme ve analiz yöntemleri (Ders notu). Çukurova Üniversitesi Ziraat Fakültesi Zootekni Bölümü, Adana.

Kün, E., 1996. Tahıllar-I (Serin İklim Tahılları). Ankara Üniversitesi Ziraat Fakültesi Yayınları, Yayın No: 1451, Ankara.

Mut, Z., Aydın, N., Bayramoğlu, H.O., Özcan. H., 2010. Stability of some quality traits in bread wheat (Triticum aestivum L.) genotypes. J. Environ. Biol., 31: 489-495.

Mut, Z., Sirat, A., Sezer, İ., 2014. Samsun koşullarında bazı iki sıralı arpa (Hordeum vulgare conv. distichon) genotiplerinde tane verimi ile başlıca tarımsal özelliklerin belirlenmesi ve stabilite analizi. YYÜ Tarım Bilimleri Dergisi, 24(1): 60-69.

Mut, Z., Ö. D. Erbaş, H. Akay, 2017. Bazı Ekmeklik Buğday (Triticum aestivum L.) Çeşitlerinin Tane Verimi ve Kalite Özelliklerinin Belirlenmesi. Anadolu Tarım Bilimleri Dergisi, 32(1):85-95. doi: 10.7161/omuanajas.288862

Oral, E. Kendal, E., Doğan, Y. 2017. Bazı yazlık arpa (Hordeum vulgare L.) genotiplerinin verim ve kalite yönünden değerlendirilmesi. Iğdır Üniversitesi Fen Bilimleri Enstitüsü Dergisi, 7(1): 31-38. doi: 10.21597/jist.2017.82

Öztürk. İ., Avc1. R., Kahraman, T. 2007 Trakya Bölgesi'nde yetiştirilen bazı arpa (Hordeum vulgare L) çeşitlerinin verim ve verim unsurları ile bazı kalite özelliklerinin belirlenmesi. Trakya Üniv. Zir. Fak. Dergisi, 21 (1): 59-68.

Ragaee, S., El-Sayed M., Abdel-Aal, S. A., And Noaman, M., 2006. Antioxidant activity and nutrient composition of selected cereals for food use, Food 
Chemistry,

98:

doi:10.1016/j.foodchem.2005.04.039

SAS, 1998. INC SAS/STAT users' guide release 7.0, Cary, NC, USA.

Sirat, A., Sezer, İ., 2013. Samsun Ekolojik Koşullarında Bazı İki ve Altı Siralı Arpa (Hordeum vulgare L.) Genotiplerinin Verim ve Verim Unsurları İle Kalite Özelliklerinin Belirlenmesi. YYÜ Tarım Bilimleri Dergisi, 23(1): 10-17.

Sirat, A. Sezer, İ. 2017. Samsun ekolojik koşullarında bazı iki siralı arpa (Hordeum vulgare conv. distichon) çeşitlerinin verim, verim unsurları ile bazı kalite özelliklerinin incelenmesi. Akademik Ziraat Dergisi, 6(1):23-34.

Sönmez, F. Yılmaz, Y. 2000. Azot ve fosforun arpa tanesinin bazı makro ve mikro besin maddesi içerikleri üzerine etkisi. Tarım Bilimleri Dergisi, 6(2): 65-75.
Topal A., 1993. Konya ekolojik şartlarında bazı arpa çeşitlerinde (Hordeum vulgare L.) farklı ekim zamanlarının kışa dayanıklılık, dane verimi, verim unsurları ve kalite özelliklerine etkileri üzerine bir araştırma. Doktora Tezi, Selçuk Üniversitesi Fen Bilimleri Enstitüsü,107s, Konya.

TÜİK, 2017. Türkiye İstatistik Kurumu. Bitkisel üretim istatistikleri. $/$ medas $/$ $\mathrm{kn}=92 \&$ locale $=\operatorname{tr} \quad$ [Erişim tarihi: 8 Ekim 2018].

Van Soest, P.J., Robertson J.B., Lewis, B.A., 1991. Methods for dietary fiber, neutral detergent fiber, and nonstarch polysaccharides in relation to animal nutrition. J. Dairy Sci., 74(10): 3583-3597.

Zhang, G., Hamaker, B. R., 2017. The nutritional property of endosperm starch and its contribution to the health benefits of whole grain foods. Critical Reviews in Food Science and Nutrition, 57(18): 3807-3817. doi: 10.1080/10408398.2015.1130685 